\title{
Front Matter: Volume 11770
}

, "Front Matter: Volume 11770," Proc. SPIE 11770, Nonlinear Optics and Applications XII, 1177001 (11 May 2021); doi: 10.1117/12.2598953

SPIE. Event: SPIE Optics + Optoelectronics, 2021, Online Only 


\section{PRO CEEDINGS OF SPIE}

\section{Nonlinear Optics and Applications XII}

Mario Bertolotti

Anatoly V. Zayats

Alexei M. Zheltikov

Editors

19-23 April 2021

Online Only, Czech Republic

Sponsored by

SPIE

Cooperating Organisations

EU Bea mlines (Czech Republic)

Laserlab Europe

European Optic al Soc iety

HiLASE Centre (Czech Republic)

Published by

SPIE 
The papers in this volume were part of the technical conference cited on the coverand title page. Papers were selected and subject to review by the editors and conference program committee. Some conference presentations may not be available for publication. Additional papers and presentation recordings may be a vaila ble online in the SPIE Digital Libra ry at SPIEDigita lLibrary.org.

The papers reflect the work and thoughts of the authors and a re published herein as submitted. The publisher is not responsible for the valid ity of the information or for any outc omes resulting from reliance thereon.

Please use the following format to cite material from these proceedings:

Author(s), "Title of Paper," in Nonlinear Optics and Applications XII, edited by Mario Bertolotti, Anatoly V. Zayats, Alexei M. Zheltikov, Proc. of SPIE 11770, Seven-digit Article CID Number (DD/MM/YYYY); (DOIURL).

ISSN: 0277-786X

ISSN: 1996-756X (electronic)

ISBN: 9781510643741

ISBN: 9781510643758 (electronic)

Published by

SPIE

P.O. Box 10, Bellingham, Wa shington 98227-0010 USA

Telephone +1 3606763290 (Pacific Time)

SPIE.org

Copyright @ 2021 Society of Photo-Optic al Instrumentation Engineers (SPIE).

Copying of material in this book for intemal or personal use, orfor the intemal or personal use of specific clients, beyond the fair use provisions granted by the U.S. Copyright Law is authorized by SPIE subject to payment of fees. To obta in permission to use and share a ricles in this volume, visit Copyright Clearance Center at copyright.com. Other copying for republication, resale, a dvertising or promotion, or any form of systematic or multiple reproduction of any material in this book is prohibited except with permission in writing from the publisher.

Printed in the United States of Americ a by Curran Associates, Inc., under license from SPIE.

Public ation of record for individual papers is online in the SPIE Digital Library.

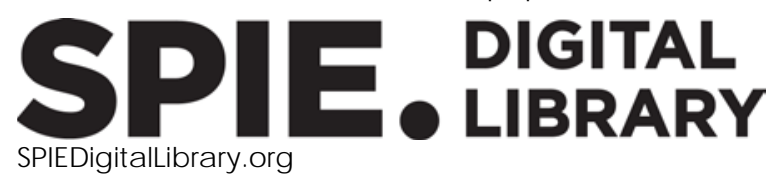

\footnotetext{
Paper Numbering: A unique c itation identifier (CID) number is assigned to each article in the Proceedings of SPIE at the time of public ation. Utilization of CIDs allows artic les to be fully citable as soon as they are published online, and connects the same identifier to all online and print versions of the publication. SPIE uses a seven-digit CID article numbering system structured as follows: - The first five digits correspond to the SPIE volume number.

- The last two digits indic ate public ation order within the volume using a Base 36 numbering system employing both numera ls and letters. These two-number sets start with $00,01,02,03,04$, 05, 06, 07, 08, 09, 0A, 0B ... 0Z, followed by 10-1Z, 20-2Z, etc. The CID Number appears on each page of the manuscript.
} 


\section{Contents}

PLASMONICS

1177005 Chiral nanosurfaces for enhancement of local electromagnetic field [11770-2]

NONUNEARTIES

11770 OD High-intensity light bullets at the competition of quadratic and cubic nonlinearities [11770-10]

$11770 \mathrm{OE} \quad$ Generation of stable "dancing" two-component optical bullets [11770-11]

11770 OG Slicon metasurfaces with bound states in the continuum for high-hamonic generation [11770-13]

RAMAN

11770 OK Generation of terahertz signal by photomixing Kelly sidebands of mode-locking fiber laser [11770-17]

$11770 \mathrm{OL}$ Features of the dynamics of Bragg gratings inscription with femtosec ond radiation [11770-18]

11770 ON Femtosec ond laser reconstruction of graphene field effect transistor [11770-20]

QUADRATIC MATERIALS

11770 OP Design study of efficient far-UVC second-hamonic generation using an integrated approach [11770-22]

$117700 \mathrm{Q}$ Themal influence on laser self-injection locking to nonlinear mic roresonator [11770-23]

11770 OR Mode-locking features in a sub-200-fs erbium-doped all-fiber laser based on high-density wellaligned single-walled carbon nanotubes [11770-24]

\section{MATERIALS}

11770 0S Hamonic generation at the nanoscale in strategic materials for nanophotonics (Keynote Paper) [11770-25] 
11770 0X Hamonic generation from gold nanolayers: bound and hot electron contributions [11770-30]

11770 oY Enhanced second-hamonic generation by single metal-insulatormultilayered nanocavities with axial symmetry resonating in the near-infrared [11770-31]

$117700 Z$ Second hamonic generation in colloidal solution of heterostructured CdSe/CdS quantum wells [11770-32]

1177010 Peculianities of exciton interaction and relaxation in colloidal CdSe/C dS nanoplatelets [11770-33]

\section{APPUCATIONS}

$1177013 \quad$ Resenoir computing with optical solitons [11770-36]

$1177014 \quad$ Adaptive camera calibration for a foc us adjustable liquid lens in fiber optic endoscopy [11770-37]

1177015 Surface enhanced Raman scattering of crystal violet [11770-38]

1177016 Fixed-point realisation of fast nonlinear Fourier transform algonithm for FGA implementation of optical data processing [11770-39]

$1177017 \quad$ Versatile supercontinuum generation by using $X^{(2)}$ and $X^{(3)}$ nonlinearities in PPLN crystal for direct multiplex CARS measurement [11770-40]

1177018 Analogue cosmology: using tec hniques from nonlinear optics to study modified theories of gravity with non-minimal coupling between c urvature and matter [11770-41]

$1177019 \quad$ High-resolution mid-MIR spectrally resolved interferometry [11770-42]

11770 1C Random fiber laser with switchable repetition rate [11770-45]

\section{POSTER SESSION}

$1177011 \quad$ Nonlinear photoionization of supersonically expanded molec ular pulses of iodomethane (CH [11770-51]

$117701 \mathrm{~K} \quad$ Dual-frequency namowband CW fiber laser implementing self-injection locking of DFB laser diode and Brillouin lasing in a single ring cavity [11770-53]

$117701 \mathrm{~L} \quad$ Peculiar features of surface plasmon-polariton modulation instability in a metal film with varying thic kness [11770-54]

$117701 M \quad$ Mic rowave signal generation with a dual-frequency self-injection-locked DFB laser [11770-55] 
$117701 \mathrm{~N} \quad$ Stable hamonic mode locking in soliton fiber laser with frequency shift theory and experiment [11770-56]

$1177010 \quad$ Oscillations of photoc ument signals upon photoionization of polanized Arand Xe atoms in magnetic fields [11770-57]

11770 1P Photoinduced trap passivation for enhanced photoluminescence in 2D organic-inorganic hybrid perovskites [11770-58]

$117701 \mathrm{Q}$ Excitation of a bound state in the continuum in nonlinear systems from the far field [11770-59]

11770 IR Barkhausen conditions and starting of an optoelectronic oscillator [11770-60]

1177015 Investigation of the level of uncertainty given by Brillouin light scattering [11770-61]

$117701 T$ Theorical calc ulations on nonlinear optical properties of choline chloride-urea deep eutectic solvent [11770-62]

$117701 \mathrm{U}$ Superfluid effects in defoc using nematic liquid crystals [11770-63]

$117701 \mathrm{~V}$ Exploning quantum-like turbulence with a two-component paraxial fluid of light [11770-64]

11770 1W Optical limiting properties of J-type dimeric phthalocyanine $\mathrm{Cu}$ and optical switching based on spatial self-phase modulation [11770-65]

$117701 X \quad$ Interferometric Z-scan method forthermo-optical effect studies [11770-66] 
Proc. of SPIE Vol. 11770 1177001-6

\section{Downloaded From: https://www.spiedigitallibrary.org/conference-proceedings-of-spie on 26 Apr 2023
Terms of Use: https://www.spiedigitallibrary.org/terms-of-use}

